\title{
The Internationalisation of Higher Education in Ireland and its Impact on Language Policy: A Qualitative Document Analysis
}

\author{
Carmen Maria Ortiz Granero \\ Trinity College Dublin \\ ortizgrc@tcd.ie
}

\begin{abstract}
This paper studies the effect of internationalisation in Irish higher education on the language element of policies and strategies, and provides an insight of the current approaches towards language in higher education. The author explores the language-related trends over time in national public records, as well as the current linguistic targets reflected in European, national and institutional strategies by means of Qualitative Document Analysis (QDA). The evaluation shows a shift from the focus on inward mobility and the efforts for meeting international students' linguistic needs, to an internationalised higher education system that requires the expansion of outward mobility and domestic students' linguistic repertoire. Although Irish higher education institutions (HEIs) present the perfect context for becoming leaders in linguistic internationalisation practices, the scant consideration given to language in institutional strategies together with the lack of explicitness in existing national strategies result in language prevailing as a major issue for both, international and domestic students.
\end{abstract}

Keywords: Internationalisation; higher education; language policy; Qualitative Document Analysis

\section{Introduction}

For the past three decades, the internationalisation of higher education has become a topic of increasing interest among researchers and policy makers, as it has been placed at the core of most governmental and institutional strategies (see for example Department of Education and Skills, 2016; University College Dublin, 2016). Despite the emphasis and value attributed to internationalisation in higher education worldwide, this topic has received relatively little attention in Ireland as highlighted in the recent study conducted by Clarke, Hui Yang and Harmon (2018). Given that the internationalisation of higher education has been acknowledged 
as shaped by policies and strategies at the national and institutional level (Altbach, Reisberg, \& Rumbley, 2009), a systematic analysis of the internationalisation policies and strategies affecting Irish higher education would provide a better understanding of the attitudes towards language in those. Thus, this paper explores the linguistic aspects present in Irish higher education public records with the aim of providing an answer to the two research questions that guided the research:

RQ1. How have higher education national policies and strategies changed in relation to language as a consequence of increasing internationalisation?

RQ2. What are the linguistic goals in current internationalisation policies and strategies regarding higher education at the three levels (supranational, national, and institutional)?

The concept of internationalisation is recognised as multifaceted and constantly evolving; and it is primarily due to this fact that no agreement has been reached on establishing a universally accepted definition (Altbach et al., 2009). Despite the number of attempts to frame the concept, Knight's (2008) definition continues being the most widely acknowledged, seemingly attributed to its inclusivity and application to different times, spaces and contexts. This definition regards internationalisation of higher education as the integration of an 'international, intercultural and global dimension into the purpose, functions or delivery of post-secondary education' (Knight, 2008, p.11). Therefore, internationalisation of higher education comprises all those practices that contribute to a more comprehensive education system. More recently, De Wit (2015, p.3) has expanded this definition by adding- 'in order to enhance the quality of education and research for all students and staff, and to make meaningful contribution to society'. In this way, clarifying the aim of internationalisation by highlighting its role in society through the assurance of high-quality education and research. However, although this definition encompasses the most prevalent aims of internationalisation in different contexts, the concept should be constantly redefined due to its continuous evolving character, as suggested by Knight (2008).

Internationalisation is widely regarded as a response of higher education to the economically driven phenomenon of globalisation; and while globalisation is seen as the 'uncontrollable' process that shapes society, internationalisation is tailored by governmental and institutional strategies (Altbach et al., 2009). Nonetheless, despite the fact that internationalisation of higher 
education has been related to positive aspects, including cooperation and quality in education, and globalisation in higher education has been associated with economic competition and education as a business (van Vught, van der Wende, \& Westerheijden, 2002), this does not exclude the undeniable position that the economic factor occupies in the higher education sector. Universities around the world have then faced pressure to internationalise their practices as a consequence of the economic benefits associated with student mobility.

The following two sections are devoted to the review of the literature. While section two presents the origins and development of the internationalisation of higher education in Ireland, followed by an outline of the current strategies that are shaping the internationalisation of Irish higher education; section three provides a picture of the internationalisation of higher education with a specific focus on language, first in the Anglophone context, and then in the Irish context. These are followed by the methodology, and an analysis and discussion that provide a systematic review of the internationalisation policies and their linguistic approaches as a first step to identify the aims and regulations concerning the linguistic challenges faced by international and domestic students in Irish HEIs.

\section{Higher Education Strategies in Ireland}

\subsection{Origins and development}

Although the majority of European countries saw an increase in the number of international students and international activities during the decades of the 1960s and 1970s, mainly as a result of the Joint Study Programme launched in 1976 (Council and Ministers, 1976), Ireland did not experience a significant rise in inward mobility until the late 1980s onwards (Walsh, 2011). Until the 1960s, the Irish higher education was an elitist system. The educational reform introduced by Taoiseach Seán Lemass, influenced by human capital theory and adopted by the Organisation for Economic Co-operation and Development (OECD), marked a turning point in the history of higher education in Ireland (Walsh, 2011). This idea of investment in human capital, seen as essential for economic growth, situated higher education as a key driver for economy, and resulted in an increased access to higher education and the expansion of enrolments in tertiary institutions from the 1960s (Walsh, 2014). In this context, the Irish Council for International Students (ICOS) started its work by providing voluntary support to the small number of international students in Ireland that at that time was mostly comprised of medical and engineering undergraduates from African mission-related mobility practices (Cox, 1996). During the next two decades, the proportion of international students remained low with 
some students coming from the United Kingdom, Asia, Africa, very few Europeans, and exchange students from North America (Cox, 1996, p. 95). This small number of foreign students compared to other European countries was the result of a combination of highly selective entry criteria, high tuition fees and lack of former colonial ties (Cox, 1996, p. 95).

In the mid 1980s, the European Community formulated a research and development policy with the purpose of competing with the United States, which had recently lost its dominance and had been replaced by Japan as the world's leading economic power (Cox, 1996). Thus, the European Commission incentivised collaboration for curriculum development, mobility programmes and education-industry partnerships among governments, and introduced the European Action Scheme for the Mobility of University Students (Erasmus) (de Wit \& Merkx, 2012, p. 53). The Erasmus scheme not only contributed to the highest rise in internationalisation up to that point, but also established certain standards and influenced governments and institutions in their policies, that until that time were characterised for being 'overwhelmingly voluntarist, unorganised and individual' (Neave, 1992, p. 15). Irish Higher Education Institutions (HEIs) have participated in the Erasmus programme since its foundation in 1987, which resulted in a significant influx of international students from European countries. However, according to the statistics published by the ICOS (1990), during the 1980s Ireland was still situated at the bottom of the European Community in terms of foreign student numbers, with international students making up only $4 \%$ of total number of students enrolled in higher education in the academic year 1988-1989. This fact was a key incentive in the creation of a small number of Bilateral Aid Fellowships and the establishment of the Programme for Economic and Social Progress that intended to set Ireland as an 'International Education Centre' (Callan \& Steele, 1991). To date, the Erasmus programme is by far the most prolific exchange programme, and accordingly, it is considered as one of the leading practices in the promotion of cultural and linguistic diversity in Europe (Studer \& Werlen, 2012).

A defining force in European higher education in the 2000s was the signing of the Bologna Declaration in 1999 by the higher education representatives of 29 countries, including Ireland. The declaration aimed to establish a cooperative European system of higher education capable of competing internationally, and that would regard internationalisation-focused activities such as mobility schemes and curriculum development, among its key objectives (European Ministers in charge of Higher Education, 1999). However, these efforts for establishing a Europeanised higher education system have been criticised for fostering the use of English as 
lingua franca to the detriment of promoting a multilingual education (Phillipson, 2006; Doiz, Lasagabaster \& Sierra, 2013), which has been raised in subsequent strategies (e.g. 'Internationalisation of Irish Education Services' 2004). In Ireland, the Bologna Declaration did not entail a radical reform, but reaffirmed the right direction of the existing national policies, since their objectives were already largely 'Bologna compliant' (Mernagh, 2010, p. 3); and established the basis for successive internationalisation policies, including Ireland's International Education Strategy 2010-2015 'Investing in Global Relationships' (Department of Education and Skills, 2010).

\subsection{Current strategies}

In an expanding international HE environment, Europe's efforts for assuring its status over the emerging competitors such as China or India rely mostly on its reformed internationalisation policies with focus on preeminent practices abroad and at home. Through the flagship initiative 'Youth on the move', the Europe 2020 strategy intends to enhance internationalisation practices and high-quality education through the promotion of communication in foreign languages among other measures, as well as increase students' and trainees' mobility and employability opportunities (European Commission, 2010). More recently, the renewed agenda for higher education adopted by the European Commission in May 2017 reiterates the promotion of 'international cooperation, exchange and mobility to boost quality' as one of its main objectives, and lays emphasis on 'internationalisation at home' support (European Commission, 2017, p. 11). The EU counts on the Erasmust programme in education and training, and Horizon 2020 in research, as fundamental instruments to achieve these policy priorities (European Commission, 2017). The Erasmus+ programme, established in 2014, unifies all the previous EU-funded programmes in Ireland (i.e. Erasmus, Comenius, Leonardo, Grundtvi, Transversal Programmes, Youth in Action, Jean Monnet, Tempus and Erasmus Mundus), and pursues to improve key competences and skills, as well as to extend partnerships between education and employment from a centralised European perspective. It is estimated that the Erasmus+ programme will provide funding for around 135,000 students and staff exchanges outside the EU and 2 million exchanges within the EU by 2020 (European Commission, 2018). In the Irish context, the statistics for the academic year 2015/2016 showed a total of 3,173 outgoing students and 262 faculty members, and 7,579 incoming students and 707 faculty members (HEA, 2017, p. 3), which reflects the dominance of inward mobility in Irish HEIs. 
At the national level, the International Education Strategy for Ireland 2016-2020, which is grounded on the principles of the 2010-2015 Strategy, seeks to ensure an internationalised education system that creates global citizens, and becomes a market leader nation in higher education. The actions to achieve these objectives include the rise in the number of inbound international students and eminent researchers; the provision of international competitive skills and experience as well as mobility opportunities for Irish students; and the construction of global networks to attract funding and achieve social and economic outcomes (Department of Education and Skills, 2016). The strategy establishes four strategic priorities:

(a) 'A supportive national framework', in order to ensure a consensual internationalisation strategy through cohesion and collaboration by all the stakeholders at the national level, emphasising the importance of establishing strong links between relevant schemes, and relies on the first strategy for foreign languages in education 'Languages Connect, Ireland's Strategy for Foreign Languages in Education 20172026 ' as the bridge to competing effectively in foreign markets as well as ensuring foreign direct investment as key for Ireland's economic development (Department of Education and Skills, 2016, p. 7).

(b) 'Internationally-oriented, globally competitive HEIs', which involves a strategic development responsive to national and regional needs, a funding model, the provision of on-campus accommodation for international students, student recruitment and mobility, the internationalisation of the curriculum, the provision of transnational higher education, and an international student experience for domestic students and calls for HEIs to include those in their individual strategies (Department of Education and Skills, 2016, p. 8).

(c) 'Sustainable growth in the English Language Training (ELT) sector', which considers the inclusion of ELT in internationalisation plans as crucial to promote Ireland as destination for international students, supported by a growth in specialised programmes including English for Academic Purposes (EAP), English for Specific Purposes (ESP) and Foundation Pathways (Department of Education and Skills, 2016, p. 8).

(d) 'Succeeding abroad', which comprises the enhancement of pivotal international partnerships, and the promotion of Ireland as 'centre for human capital development' (Department of Education and Skills, 2016, p. 9). 
In addition to this strategy, the Irish higher education sector counts on an International Education Mark (IEM) that ensures the quality of the international practices of those HEIs authorised to its use, and contributes to the international reputation of Ireland (Quality and Qualifications Ireland, 2013). HEIs under this mark need to be compliant with the Code of Practice designed by Quality and Qualifications Ireland (QQI), that establishes the criteria for providing a well-rounded international education for overseas students and trainees (Quality and Qualifications Ireland, 2015). In its efforts to establish international networks and acquire global significance, Ireland has signed agreements with non-EU countries including Russia, Bolivia, Brazil, USA, India, Japan, China and Israel. It also encourages internationalisation through scholarships directed towards inbound mobility (Government of Ireland Scholarship), outbound mobility (International Scholarship Opportunities), and North-South mobility (Universities Ireland Scholarship) (HEA, 2016a).

\section{Language and Internationalisation}

\subsection{Language and the Internationalisation of Higher Education}

Although the impact of mobility practices on a nation or an institution has been largely addressed from the economic perspective due to its measurable nature, there are other less visible or 'hidden' benefits that these practices bring along which cannot be quantified. The literature on internationalisation, although less extensively, also identifies mobility practices effects on the academic and sociocultural dimensions (see for example Luo \& Jamieson-Drake, 2013; Knight, 2015). The presence of international students in the classroom and the efforts for internationalisation have influenced the teaching and learning processes. As a consequence, faculty are encouraged to adapt their teaching methodology, curricula and even the language of instruction in order to reach this international audience (Carroll \& Ryan, 2005). In addition, domestic students reportedly benefit the most from cross-national interactions, as it enhances their intercultural awareness, as well as linguistic, cognitive and behavioural skills (Luo \& Jamieson-Drake, 2013; Lee et al., 2012), contributing to the development of global citizenship as pursued by institutional and national policies (see Department of Education and Skills, 2011). In this global context, sharing a language for communication plays a crucial role in the successful execution of internationalisation; and as it has been already mentioned, it is through policy that internationalisation is achieved. Therefore, the formulation of language policies that address the needs of international and domestic students can be considered as key to the successful internationalisation of higher education. 
Anglophone countries have dominated internationalisation practices for three decades, which has been partly attributed to the role of English as a global language or lingua franca, and, as a result, the language of academia (see Jenkins, 2013). Data from UNESCO (2019) show that US, UK, China, Canada and Australia- in that order- are the top destination countries when it comes to attracting international students. This rank reveals two major trends: the still present dominance of anglophone countries, and the increase in the number of international students studying in non-anglophone countries, specifically China. China has seen a dramatic increase in the number of inbound students since the early 2000s that has positioned it in the top three countries, which is partly attributed to the emphasis placed on English language practices in higher education (see Mu et al., 2019).

Universities in anglophone countries have benefited from the demand of higher education in English, which on one hand has situated them as leaders in the receiving market, but at the same time at the bottom of the sending market. This has resulted in scant attention paid to the linguistic benefits of internationalisation, which has impacted on the development of domestic students' global citizenship. For example, Liddicoat (2016:2) stresses the decreasing trend of languages offered and taken in Australian universities, and argues that anglophone universities planning is commonly limited to 'monolingual' practices that respond to the needs of nonEnglish speakers, such as academic support programmes. This phenomenon has also been identified in the European context, in which the lack of language skills in anglophone countries is considered as a 'language crisis' (see Kelly, 2019; Bowler, 2020). In the case of the UK and Ireland, scholars such as Kelly (2019) and Bowler (2020) have emphasised the need for promoting language skills at the tertiary level through policy and practice as one of the ways to resolve this crisis. In addition, scholars such as Phillipson (2015) or Maringe and Foskett (2010) have determined the need for universities to implement policies that guarantee a balanced language ecology in order to ensure effective internationalisation. However, for decades, strategies at the institutional level seem to be negatively affected by a lack of specificness and clarity in national policies, as well as the lack of a shared direction among universities (see Craciun, 2018; Henard et al., 2012; Kirk et al., 2018). This is also addressed in the Irish context, in which a recent study of internationalisation in Institutes of Technology by Carthy (2018) identifies a lack of explicit policies for foreign languages that results in the dominance of English language in Irish higher education. 
As in the case of China, the Englishisation of higher education has also resulted in the increase of non-English speaking countries worldwide providing education through English as a medium of instruction (EMI), as a way to compete with internationalisation practices in the leading anglophone countries. In Europe, EMI practices in higher education have seen and still experience a dramatic growth, with numbers increasing from 123 EMI programmes in 2007 to 822 in 2014, according to the latest report (Wachter \& Maiworm, 2014). In the case of EMI, the Englishisation is considered once again as a double-edged sword that can be perceived as a threat or opportunity for higher education institutions. Thus, while this shift to EMI practices has the potential to increase inward mobility and reduce the brain drain of non-English speaking countries, this is seen as a threat to multilingualism and the use of national languages in the case of non-anglophone countries (see for example Kirkpatrick, 2011), and as a risk for anglophone universities to lose international students to countries with EMI provision (Earls, 2016).

Considering the literature on language policy and internationalisation of higher education, attention has been largely placed on the role of language policy on non-English speaking countries, as a response to EMI practices and the detrimental effect this might have on national languages (see, for example Lau \& Lin, 2017; Soler, 2019; Soler \& Gallego Balsà, 2019; Kerklaan, Moreira \& Boersma, 2008). Nevertheless, little attention has been placed on language policy in English-speaking countries and how their linguistic diversity might be affected by the emphasis of policies on providing support to non-English speaking international students, and therefore disregarding the linguistic needs of domestic students.

\subsection{The role of language in an internationalised Irish Higher Education}

Ireland as an English-speaking country has experienced the advantages and disadvantages of the hegemonic role of English in the internationalisation of higher education. One of the most notable effects has been the lack of proficiency in foreign language skills among Irish graduates and the unsatisfied demand for foreign languages in the labour market (HEA, 2018b). Even though Irish HEIs present a multilingual landscape with an estimate of over 10,000 non-native English students (HEA, 2018a), the recent emphasis on outward mobility and foreign language learning placed by strategies such as the current 'Irish Educated Globally Connected' strategy (Department of Education and Skills, 2017) reveals the need for action in these areas. This lack of proficiency in foreign languages led to the development of the first strategy for foreign languages in education, the recently published 'Languages Connect', that not only emphasises 
the need to increase the proportion of higher education students taking foreign language modules, but also to enhance outward mobility of staff and students (Department of Education and Skills, 2017).

In terms of inward mobility, Ireland's HE internationalisation has benefitted from a steady growth during the last decade (see Clarke, Hui Yang \& Harmon, 2018). Research on the factors that move international students to pursue their studies in Ireland determine 'Ireland as an English-speaking country' as a major incentive (Education in Ireland, 2013, p. 10). In a globalised world, in which English maintains its status as lingua franca, receiving instruction in English and living in an English-speaking community offers access to a wider range of educational and professional opportunities. Nevertheless, as it has been identified in other contexts (see Galloway, Kriukow \& Numajiri, 2017), this trend might decline as a result of the increase of EMI practices in outer and expanding circle countries. Along these lines, educational quality and student support are identified as the two core domains to compete with EMI countries (Department of Education and Skills, 2011). At present, all the Irish HEIs count on their individual English language programmes mainly devoted to both, facilitating international students' access to university such as International English Language Testing System (IELTS) programmes, pre-sessional EAP programmes and English Language Pathway programmes, as well as easing their academic experience through pre-sessional and insessional EAP programmes (see for example English for Academic Purposes Support Programme, 2018; English Language Courses in UCD, 2018). Yet, English language continues to be considered as the biggest adaptation challenge by international students attending Irish HEIs (ICOS, 2012b; ICOS, 2012a; Marr \& Carey, 2012; Harris-Byrne, 2017).

\section{Methodology}

As it has been determined in the previous sections, language plays a crucial role in the development and implementation of internationalisation strategies in the higher education context. In Ireland, language is a key motivator for both, inward and outward mobility, but also it is still considered as one of the main challenges among students (ICOS, 2012b; ICOS, 2012a; Marr \& Carey, 2012; Harris-Byrne, 2017; O’Brien, 2017). Thus, this paper explores the effect of the increasing internationalisation practices on national policies in relation to language in a timely manner, as well as the current linguistic targets in higher education internationalisation strategies at the three levels, namely European, national and institutional. 
In order to examine those two aspects, Qualitative Document Analysis (QDA) was chosen as a method that provides a rigorous and systematic approach to the analysis of written documents not only for its effectiveness and efficiency in the data collection process, but also for its accessibility and reliability as it involves 'non reactive' data sources (Bowen, 2009). Although QDA has been commonly employed alongside other data collection methods as a way for seeking corroboration, it is unquestionably considered as 'an important research tool in its own right' (Bowen, 2009, p. 32). In this study, the QDA approach facilitated the examination of the evolution of linguistic implications over time, as well as the comparison of current policy trends.

The first part of the research process aimed at answering the first research question (i.e. How have higher education national policies and strategies changed in relation to language as a consequence of increasing internationalisation?) and involved the analysis of 10 public records following a chronologic time sequence. Documents included: policy documents (e.g. Green Paper on Adult Education in an Era of Learning, 1998), strategic plans (e.g. National Strategy for Higher Education to 2030), and reports (e.g. Internationalisation of Irish Education Services, 2004) (see Table 1). The second research question (i.e. What are the linguistic goals in current internationalisation policies and strategies regarding higher education at the three levels (supranational, national, and institutional)?) was explored through the analysis of 15 current documents, encompassing the three levels: European (e.g. Europe 2020), national (e.g. International Education Strategy for 2016-2020), and institutional (i.e. Strategic plans of the seven Irish universities) (see Table 2).

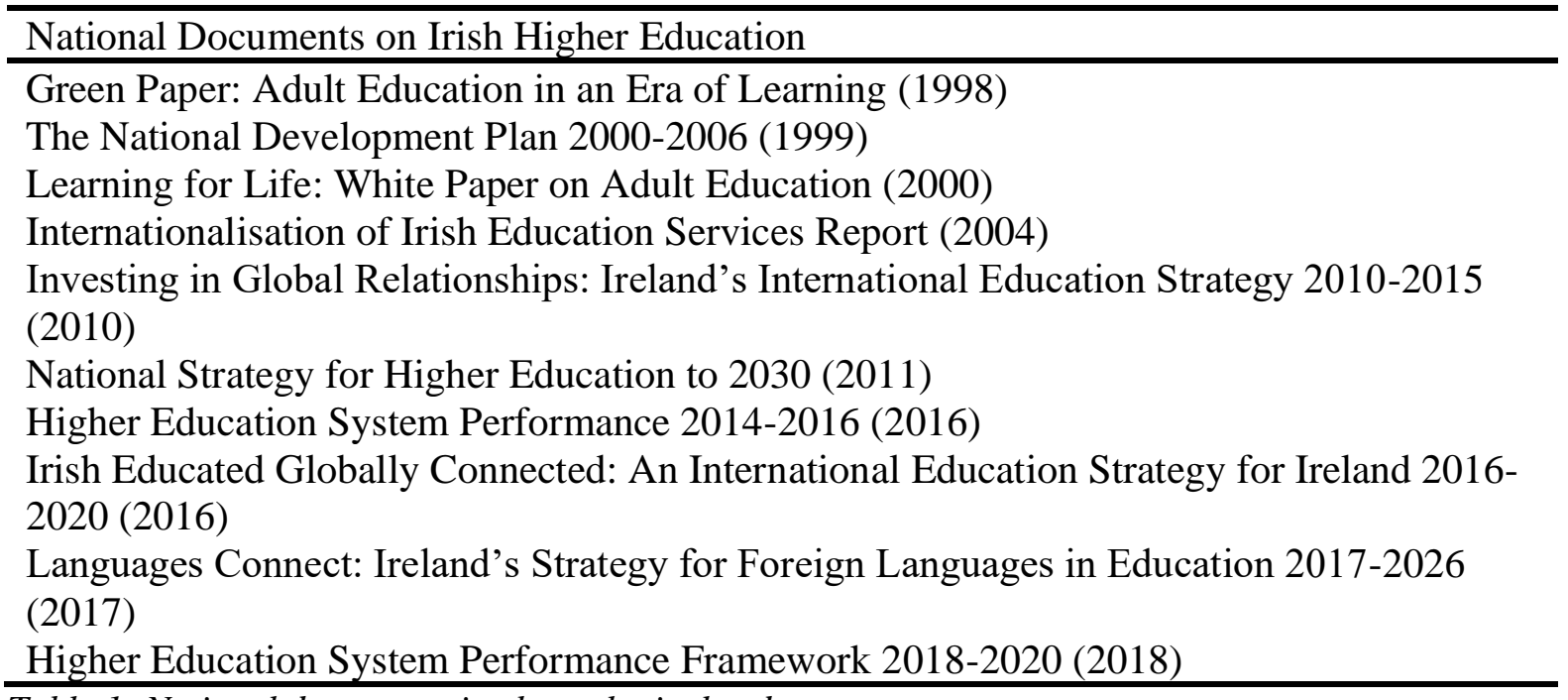

Table 1: National documents in chronological order 


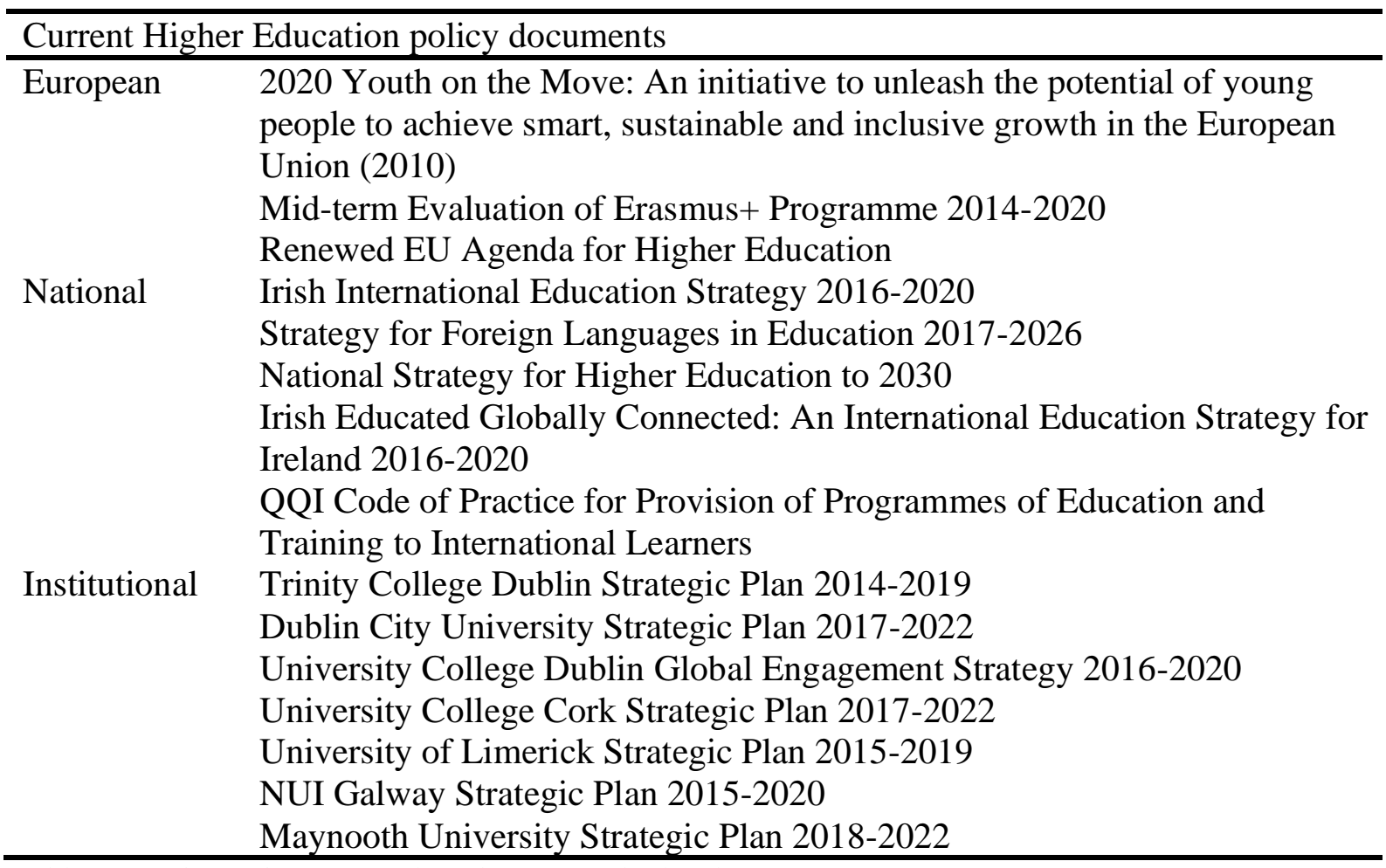

Table 2: Higher Education policy documents by level

The QDA was based on an adaptation of the stages proposed by Altheide and Schneider (2013): (1) data collection- document collection and identification of key areas; (2) data coding and organisation- the documents were coded using inductive coding; and (3) data analysisexamining themes through comparison and contrast. In this way, this thematic approach allowed a structured analysis of documents based on the emergent themes presented in Tables 3 and 4 below.

\begin{tabular}{ll}
\hline Themes & Sub-themes \\
\hline Integration and & Irish language and sign language \\
equality & Refugee Language Training \\
& Language support in higher education \\
Economic growth and & EFL role on country's economy \\
competitiveness & Quality assurance to attract learners \\
& Investment in global relationships \\
& EAP as economic growth in the ELT sector \\
& Integration between domestic and international students \\
& Pathway programmes based on EGAP \\
& Specialised programmes as core growth areas \\
Student needs & Challenge for outward mobility \\
& Lack of foreign language skills among Irish graduates \\
& Encouragement of staff and students'outward mobility
\end{tabular}


Increase number of students learning foreign languages

Table 3: National documents analysis main themes and sub-themes

\begin{tabular}{ll}
\hline Themes & Sub-themes \\
\hline Foreign languages & To ensure quality of education \\
& To succeed in the European market \\
& Promote outward mobility \\
& Promote foreign languages instruction \\
Ireland as an English- & Little attention given to foreign languages \\
speaking country & Increase inward mobility and partnerships \\
& Privileged position threatened by growth in EMI \\
& Instruction through English as major advantage \\
Language support & EAP and Pathway programmes as student support \\
& EAP, ESP and Pathway programmes as economic growth in the \\
& ELT sector \\
& Individualistic approaches by institutions \\
\hline
\end{tabular}

Table 4: Higher Education policy documents analysis main themes and sub-themes

The results and discussion are presented in the two subsequent sections and correspond to the two research questions addressed in this study.

\section{Linguistic trends in national documents}

During the late 1990s and early 2000s the Irish higher education system was marked by the still visible shift from an elitist system to mass education. The first documents on higher education, the Green Paper on Adult Education (1998) and White Paper (2000), aimed at increasing the participation of national students and were largely influenced by the lifelong learning approach established by European strategies (e.g. Lisbon Strategy, 2000). When comparing these two documents, a significant change can be observed in their approach towards integration. While the first Green Paper on Adult Education (1998) mentions Irish language and sign language as key targets for integration, the White Paper (2000) addresses language as a challenge to education and incorporates the concept of language training in order to meet the needs of immigrants, refugees and asylum seekers:

Following a Report on Access and Participation of Students with Disabilities, an extra $£ 567,000$ was allocated for special third level initiatives in this area, covering access programmes, student liaison projects, counselling services, and braille and sign language services (Department of Education and Science, 1998, p.84) 
Provision which recognises the constitutional position of Irish as the first language, along with opportunities for adults to access courses in Irish language and culture should be a feature of the evolving adult education service (Department of Education and Science, 1998, p. 86)

Refugees are entitled to the same access to education and training as Irish nationals. Within the first and second-level systems, which are catering for increasing numbers of children who are immigrants, refugees or asylum seekers, arrangements have recently been introduced to provide additional teaching resources in schools with large numbers of children for whom English is not the mother tongue. In relation to adults, a Refugee Language Support Unit has been established in Trinity College to co-ordinate language assessment and tuition on a national basis (Department of Education and Science, 2000, p. 172)

In this way, the White Paper began to acknowledge the linguistic needs of non-English speakers in education, marking the emergence of English language support in Irish adult education. These trends followed into the early 2000s and were reflected in the National Development Plan (NDP) 2000-2006 (Government of Ireland, 1999), which established 'Refugee Language Training' as one of its equality measures (Government of Ireland, 1999, p. 18).

The NDP 2000-2006 for first time identifies the role of the English as a Foreign Language sector on the country's economy and encourages its support by 'targeting new markets and segments' (Government of Ireland, 1999, p. 141). In addition, the NDP 2000-2006 recognised the learning of foreign languages as crucial for Ireland's competitiveness, although only at the primary and secondary education levels:

The promotion of a greater general proficiency in languages has been identified as a key to protecting and enhancing Ireland's competitiveness. At present, French and German are the dominant languages taught in second level schools with very low participation in other languages. (Government of Ireland, 1999, p. 103)

Under the Community Support Framework 1994-1999, a pilot programme on the teaching of European languages in primary schools was introduced [...] the Department of Education and Science initiated work to design a fuller policy on the teaching of languages which have low participation in second-level schools or are 
not available as part of current syllabi [...] it is proposed to promote wider teaching of Italian, Spanish and other languages in post-primary schools (Government of Ireland, 1999, p. 103)

The Internationalisation of Irish Education Services report that resulted from the growth in the international education services sector and its consequent visible economic impact marked a turning point in the approach to internationalisation (Department of Education and Science, 2004). This report addresses the privileged position of Ireland as an English-speaking country in terms of incoming mobility, and positions the welfare of students and their individual education experience and support as indicators of quality assurance and, therefore, are treated as 'key elements in attracting learners' (Department of Education and Science, 2004, p. 9). In this way, the report sets the foundations for the first internationalisation strategy in the Irish higher education context that was established in 2010 (Department of Education and Skills, 2010).

Following the principles established by the report in internationalisation (Department of Education and Science, 2004), the first internationalisation strategy 'Investing in Global Relationships 2010-2015' (Department of Education and Skills, 2010) positions student needs and integration between international and domestic students as core elements for a high-quality education:

The educational interests of our international students, their safety and security, their integration with the wider student body and their general experience of Ireland are central to our concerns. (Department of Education and Skills, 2010, p. 28) Ireland must offer a high-quality education, strong integration with domestic students, and an unparalleled experience that adds significant value to the career outcomes of all who are educated here. (Department of Education and Skills, 2010, p. 11)

Quality is still considered as the major competitive advantage of Irish higher education, in which students are seen as advocates overseas, and consequently regarded as an 'investment in future global relationships' (Department of Education and Skills, 2010, p. 11). Along these lines, the strategy acknowledges the existence of linguistic barriers and relies on the English Language Teaching (ELT) sector as the one providing appropriate support through the 
introduction of pathway programmes based on English for General Academic Purposes (EGAP):

The transfer of ACELS (the voluntary inspection and recognition scheme for the English-language sector) to the NQAI, the development of the Quality Mark and the development of the English for General Academic Purposes (EGAP) programme as a foundation course on the NFQ are crucial in positioning Ireland for taking advantage of new opportunities for sustainable growth and diversification in the English-language sector. (Department of Education and Skills, 2010, p.57)

These new programmes were regarded as an opportunity for the economic growth of the ELT sector (Department of Education and Skills, 2010, p. 58), which has been reflected in the current international strategy 'Irish Educated Globally Connected' that identifies specialised programme opportunities including EAP, ESP and Pathway programmes as 'core growth areas' (Department of Education and Skills, 2016, p. 8). This focus on English language skills for international students would exemplify the previously mentioned monolingual approach criticised by Liddicoat (2016).

Concurrently, the 2014-2016 Higher Education System Performance (HEA, 2016a) report identified the shortage of graduates with foreign language skills, which can be partly attributable to the hegemonic role of English in the Europeanisation of higher education (see O'Brien, 2017), and relies on the 'National Skills Strategy' in order to address this issue:

The implementation of actions in the National Skills Strategy including [...] foreign languages in education strategy $[\ldots]$ and ongoing engagement between higher education and employer interests will all contribute to addressing these issues in the coming years. (HEA, 2016a)

This new approach becomes more obvious when comparing the two international strategies (i.e. Department of Education and Skills, 2010; Department of Education and Skills, 2016). Whereas the 2010 strategy focused mainly on international students' welfare and inward mobility, the 2016 strategy also pays attention to domestic students' linguistic needs by encouraging the development of foreign language competence, as well as the important role of outward mobility practices for both, students and staff in an internationalised institution. More 
recently, the 2018-2020 Higher System Performance report uses data from the National Employer Survey (HEA, 2015) to raise the issue of the lack of foreign language skills among Irish graduates, and regards the increase of $20 \%$ of students taking foreign languages by 2026 as part of its key objectives, as specified in the key target outcomes of 'Languages Connect' (HEA, 2018b).

\section{Linguistic targets of current Higher Education policies}

The Europe 2020 flagship initiative 'Youth on the Move' considers communication in foreign languages as a key competence to ensure high-quality learning and teaching in a knowledge economy and society context, and relies on the concept of learning mobility as essential for boosting linguistic competence and as a way to equip learners with the necessary skills to succeed in the European labour market (European Union, 2010).

High quality learning and teaching should be promoted at all levels of the education system. Key competences for the knowledge economy and society, such as [...] communication in foreign languages [...] have become ever more important. (European Union, 2010, p. 6)

Learning mobility is an important way in which young people can strengthen their future employability and acquire new professional competences, while enhancing their development as active citizens. (European Union, 2010, p. 10)

Under these terms, the mid-term evaluation of Erasmus+ in Ireland identifies the little attention given to foreign language learning, in common with other English-speaking countries, and proposes 'an increase in participation in Erasmus + as a measure towards improving language proficiency' (O'Brien, 2017, p. 9). Accordingly, the Irish International Education Strategy 2016-2020 includes the promotion of foreign languages and outward mobility among its strategic priorities, supported by the recent Strategy for Foreign Languages in Education 20172026 that calls for HEIs to improve the access and participation of students to foreign language instruction but fail to provide specific guidelines or recommendations (Department of Education and Skills, 2017).

Outward mobility by Irish staff members and students will be encouraged. (Department of Education and Skills, 2016, p. 14) 
Foreign Direct Investment has also played a significant role in advancing Ireland's economic development over the past decades. In order to continue to compete effectively for foreign direct investment, we must continue to show that we have the talent and skills required, including language skills. (Department of Education and Skills, 2016, p. 27)

Increase the proportion of the higher education cohort studying a foreign language, in any capacity, as part of their course to 20\%. (Department of Education and Skills, 2017, p.19)

In an increasingly competitive higher education context, national and European documents contemplate the preeminent position of Ireland as one of only two member states in the European Union in which English is an official language, as a result of Brexit recent referendum, which according to O'Brien (2017, p. 15) 'may lead to an increase in inward mobility and partnership requests'. Nevertheless, Ireland's advantageous position has been lately threatened by the growth in EMI institutions, and hence, Irish HEIs need to assure a competitive high-quality education (Department of Education and Skills, 2011). Integration and support have been contemplated in national strategies, in which language support relies mostly on EAP and Pathway programmes as the way to meet students' linguistic needs.

These programmes include those for academic or specific business purposes, while the products will feature opportunities for internships, pathways to higher education and teacher training courses. (Department of Education and Skills, 2016, p. 8)

The significance of language support is also included in the QQI Code of Practice according to which institutions 'shall offer support to international learners with English as a second language within the learning environment' (Quality and Qualifications Ireland, 2015, p. 11). However, when looking at English language support in national documents EAP, ESP and Pathway programmes are considered as part of the English Language Training (ELT) sector, and from an economic point of view (see Department of Education and Skills, 2011; Department of Education and Skills, 2016). Thus, English language support is left to the discretion of individual institutions without any established requirements, guidelines or coordination. 
A comparative analysis of the individual internationalisation strategic plans adopted by the seven universities in the Republic of Ireland (i.e. Trinity College Dublin, Dublin City University, University College Dublin, University College Cork, Maynooth University, University of Limerick, and NUI Galway) determines three common goals: increasing mobility and partnerships, attracting a larger number of international students, and improving reputation. As disclosed in the previous sections, these three goals are highly related to language. However, little attention is paid to the role of language in such strategies, establishing a gap between the institutional level and the other two higher levels. Of the seven strategies examined, only two address the encouragement of foreign language development in line with European and national strategies, and only one mentions language support for international students as a way of meeting their needs and the encouragement and access of modern languages as established by the Code of Practice (Quality and Qualifications Ireland, 2015). These findings corroborate those by Carthy (2018) in her recent study on Irish Institutes of Technology, as well as the literature on other countries that have considered the lack of clarity and a shared direction as key aspects affecting effective internationalisation at the institutional level (see Craciun, 2018; Henard et al., 2012; Kirk et al., 2018).

\section{Conclusion}

The internationalisation efforts made by European and national bodies during the past three decades have led to an exemplary increase in mobility practices among higher education students and faculty, therefore facilitating the cultural and linguistic diversity of HEIs and countries. However, although mobility can be seen as a key for internationalisation, action needs to be taken at the three levels (supranational, national and institutional) in order to ensure effective internationalisation practices.

Ireland has moved from being situated at the bottom of the European Commission, to occupy a leading position largely due to the role of English as the language of internationalisation par excellence. This dominant position might be threatened by the emerging global phenomenon of EMI, that urges Irish higher education to exceed in quality and compete with other nonEnglish-speaking countries. In the same vein, European policies have prioritised English as the lingua franca, largely promoting foreign language acquisition among non-English-speaking countries, yet disregarding the benefits of linguistic diversity in English-speaking countries. 
The analysis of national documents reflected the transition from nationally-oriented strategic efforts in rising the number of Irish students in HEIs during the 1990s as a consequence of the Irish HE system elitist background, to a focus on international students' attraction and the importance of addressing their linguistic needs with the introduction of English language support in the 2000s. More recently, the latest strategy on internationalisation at the national level encompasses the focus on international students established by the previous strategy, and also intends to respond to the need for the promotion of outward mobility practices and foreign language skills.

When comparing policies at the different levels, European and national policies address the importance of linguistic competence for the internationalisation process, while institutional policies rely on mobility and recruitment objectives, accentuating the gap between national and institutional policies. It is however imperative to address the fact that national policies demand the provision of English language support for international students and an increase in foreign language learning among domestic students but fail to provide specific guidelines or recommendations for practice, which results in an individualistic and uncoordinated approach from institutions.

Thus, this study has presented a key and timely contribution to the field of internationalisation in higher education in Ireland, with a focus on the language element of policies. Firstly, by analysing the language aspects of national policies and strategies concerning higher education, which gives an outline of the changes that have resulted from the increase in internationalisation practices; and secondly, by identifying the current targets in internationalisation policies involving language. These are contemplated as a first step to address gaps in policy that are reflected in the current language related challenges faced by both, international and domestic students in Irish HEIs. Therefore, the study would serve as a cornerstone for future studies regarding language in internationalisation policy and strategies in the Irish higher education system, involving primary research and a variety of methods, since the current study might be limited by its dependability on secondary sources and the use of a single method. 


\section{References}

Bowen, G. A. (2009). 'Document Analysis as a Qualitative Research Method', Qualitative Research Journal, (9)2:27-40.

Bowler, M. (2020). A Language Crisis? HEPI number 123. Retrieved from: https://www.hepi.ac.uk/2020/01/09/a-languages-crisis/

Callan, H. \& Steele, K. (1991). Student Flow and National Policy in the European Community. London: Commonwealth Secretariat and United Kingdom Council for Overseas Student Affairs.

Carroll, J. \& Ryan, J. (2005). Teaching International Students: Improving Learning for All. Oxon: Routledge.

Carthy, U. (2018). 'Language Policy in an era of Globalisation: Some recent Research from the Higher Education Sector in the Republic of Ireland', TEANGA 25, 15-33.

Clarke, M., Hui Yang, L., \& Harmon, D. (2018). The Internationalisation of Irish Higher Education. Retrieved from: http://eurireland.ie/assets/uploads/2018/07/report_internationalisation_of_education_20 18.pdf

Craciun, D. (2018) National Policies for Higher Education Internationalization: A Global Comparative Perspective. In: Curaj A., Deca L., Pricopie R. (Eds.) European Higher Education Area: The Impact of Past and Future Policies. Cham: Springer.

Council and Ministers of Education meeting within the Council (1976). Resolution of the Council and of Mininsters meeing within the Council of 9 Febrary 1976 comprising an action programme in the field of education. OJ C 38,19.2.1976. Retrieved from: https://eur-lex.europa.eu/legal-content/EN/TXT/?uri=CELEX\%3A41976X0219

Cox, W. (1996). ICOS and International Students. In: O. Egan (Ed.), Minority ethnic groups in higher education (pp. 94-104). Cork: Higher Education Equality Unit.

Daly, M. E. (2016). Sixties Ireland: reshaping the economy, state and society, 1957-1973. Cambridge: Cambridge University Press.

De Wit, H. \& Merkx, G. (2012). The history of internationalisation of higher education. In D. Deardoff, H. de Wit, \& T. Adams (Eds.), The SAGE Handbook of International Higher Education (pp. 43-59). Thousand Oaks: Sage.

Department of Education and Science (1998). Green Paper: Adult Education in an Era of Learning. Retrieved from: http://www.onestepup.ie/download/pdf/green_paper_on_adult_education_1998.pdf 
Department of Education and Science (2000). Learning for Life: White Paper on Adult

Education. Retrieved from: http://edepositireland.ie/handle/2262/79878

Department of Education and Science (2004). Internationalisation of Irish Education

Services. Report of Interdepartmental Working Group. Retrieved from:

https://www.education.ie/en/Publications/Policy-Reports/Internationalisation-of-Irish-

Education-Services-Report-of-Interdepartmental-Working-Group.pdf

Department of Education and Skills (2010). Investing in Global Relationships: Ireland's

International Education Strategy 2010-2015. Retrieved from:

https://www.education.ie/en/Publications/Policy-Reports/Ireland-s-International-

Education-Strategy-2010-2015-Investing-in-Global-Relationships.pdf

Department of Education and Skills (2011). National Strategy for Higher Education to 2030.

Report of the Strategy Group. Retrieved from:

http://hea.ie/assets/uploads/2017/06/National-Strategy-for-Higher-Education-2030.pdf

Department of Education and Skills (2016). Irish Educated Globally Connected: An

International Education Strategy for Ireland, 2016-2020. Retrieved from:

https://www.education.ie/en/Publications/Policy-Reports/International-Education-

Strategy-For-Ireland-2016-2020.pdf

Department of Education and Skills (2017). Languages Connect: Ireland's Strategy for

Foreign Languages in Education 2017-2026. Retrieved from:

https://www.education.ie/en/Schools-Colleges/Information/Curriculum-and-

Syllabus/Foreign-Languages-Strategy/fls_languages_connect_strategy.pdf

Doiz, A, Lasagabaster, D. \& Sierra, J. M. (2013). English-medium instruction at universities:

Global challenges. Bristol: Multilingual Matters.

Dublin City University (2017). Talent, Discovery and Transformation: Strategic Plan 2017-

2022. Retrieved from:

https://www.dcu.ie/sites/default/files/marketing/digitalmedia/presidents-

office/strategic-plan/index.html

Earls, C. W. (2016). Evolving Agendas in European English-Medium Higher Education:

Interculturality, Multilingualism and Language Policy. New York: Palgrave.

Education in Ireland (2013). Consultation on Ireland's International Strategy: Report on the findings of the ICOS and USI Focus Groups 2013. Retrieved from:

https://www.icosirl.ie/eng/about_icos/publications/2013_ICOS_Focus_Group_Findings _Final_Report.pdf 
English for Academic Purposes Support Programme (2018). Retrieved from:

http://www.nuigalway.ie/englishlanguage/englishforacademicpurposeseapsupportprogr amme/

English Language Courses in UCD (2018). Retrieved from:

https://www.ucd.ie/alc/programmes/english/

European Commission (2010). Communication from the Commission, Europe 2020: a

strategy for smart, sustainable and inclusive growth. Retrieved from:

http://ec.europa.eu/eu2020/pdf/COMPLET\%20EN\%20BARROSO\%20\%20\%20007\% 20-\%20Europe\%202020\%20-\%20EN\%20version.pdf

European Commission (2017). Communication from the Commission to the European

Parliament, the Council, the European Economic and Social Commitee and the

Committee of the Regions on a Renewed EU Agenda for Higher Education. Retrieved from: http://eur-lex.europa.eu/legal-

content/EN/TXT/PDF/?uri=CELEX:52017DC0247\&from=EN

European Commission (2018). Erasmus+ Key Figures. Retrieved from:

https://ec.europa.eu/programmes/erasmus-plus/about/key-figures_en

European Ministers in charge of Higher Education (1999). The Bologna Declaration of 19

June 1999: Joint declaration of the European Ministers of Education. Retrieved from:

https://www.eurashe.eu/library/modernising-phe/Bologna_1999_Bologna-

Declaration.pdf

European Union (2010). Youth on the Move: An initiative to unleash the potential of young people to achieve smart, sustainable and inclusive growth in the European Union.

Retrieved from: http://europa.eu/youthonthemove/docs/communication/youth-on-themove_EN.pdf

Galloway, N., Kriukow, J. \& Numajiri, T. (2017). Internationalisation, higher education and the growing demand for English: an investigation into the English medium of instruction (EMI) movement in China and Japan. Retrieved from: https://www.teachingenglish.org.uk/sites/teacheng/files/H035\%20ELTRA\%20Internati onalisation_HE_and $\% 20$ the $\% 20$ growing\%20demand\%20for\%20English\%20A4_FINA L_WEB.pdf

Government of Ireland (1999). The National Development Plan 2000-2006. Dublin: The Stationery Office. 
HEA (2015). National Employer Survey: Employers' views on Irish further and higher education and training. Retrieved from: http://hea.ie/assets/uploads/2017/06/NationalEmployer-Survey.pdf

HEA (2016a). Higher Education System Performance 2014-2016. Retrieved from: http://hea.ie/assets/uploads/2017/06/Higher-Education-System-Performance-20142016.pdf

HEA (2016b). Brexit and Irish Higher Education and Research: Challenges and Opportunities. Retrieved from: http://hea.ie/assets/uploads/2017/06/Brexit-And-IrishHigher-Education-And-Research-Challenges-And-Opportunities.pdf

HEA (2017). Erasmus+ 2015 to 2017: an overview. Retrieved from: http://eurireland.ie/assets/uploads/2017/07/Erasmus-an-Overview-2015-to-2017-printJuly-2017.pdf

HEA (2018a). Student Numbers in Ireland. Retrieved from: http://hea.ie/statistics/

HEA (2018b). Higher Education System Performance Framework 2018-2020. Retrieved from: http://hea.ie/assets/uploads/2018/01/higher-education-system-performanceframework-2018-2020.pdf

Hobsons (2014). Beyond the data: Influencing international student decision making. Retrieved from: https://www.hobsons.com/res/Whitepapers/23_Beyond_The_Data_Influencing_Interna tional_Student_Decision_Making.pdf

ICOS (1990). Statistics of overseas students in Ireland. Dublin.

ICOS (2012a). Listening to the Experience of International Students in Ireland - Cork 2012. Retrieved from: https://www.icosirl.ie/eng/about_icos/publications/2012_Cork_Forum_Report.pdf ICOS (2012b). Listening to the Experience of International Students in Ireland - Dublin 2012. Retrieved from: https://www.icosirl.ie/eng/about_icos/publications/2012_Dublin_Forum_Report.pdf

Jenkins, J. (2013). English as a Lingua Franca in the International University. Oxon: Routledge.

Kelly, M. (2019). Is the UK in a language crisis? Retrieved from: https://www.britishcouncil.org/voices-magazine/uk-language-learning-crisis Kerklaan, V., Moreira, G. \& Boersma, K. (2008). 'The Role of Language in the Internationalisation of Higher Education: an example from Portugal', European Journal of Education, 43(2):241-255. 
Kirk, S. H., Newstead, C., Gann, R. \& Rounsaville, C. (2018). 'Empowerment and ownership in effective internationalisation of the higher education curriculum', Higher Education, 76, pp. 989-1005.

Kirkpatrick, A. (2011). Internationalization or Englishization: Medium of instruction in today's universities. Hong Kong: Centre for Governance and Citizenship, The Hong Kong Institute of Education.

Knight, J. (2015). 'New Rationales Driving Internationalization', International Higher Education 34:3-5.

Lau, K. \& Lin, C.Y. (2017). 'Internationalization of higher education and language policy: the case of a bilingual university in Taiwan', Higher Education, 74(3):437-454.

Lee, A., Poch, R., Shaw, M. \& Williams, R. D. (2012). Engaging diversity in undergraduate classrooms: a pedagogy for developing intercultural competence. San Francisco: Jossey-Bass.

Liddicoat, A. J. (2016) 'Language planning in universities: teaching, research and administration', Current Issues in Language Planning, 17(3-4):231-241.

Luo, J. \& Jamieson-Drake, D. (2013). 'Examining the Educational Benefits of Interacting with International Students', Journal of International Students, 3(2):85-101.

Maringe, F. \& Foskett, N. (2010). Globalization and universities. In F. Maringe \& N. Foskett (Eds.) (2010) Globalization and Internationalization in Higher Education, (pp. 1-16). London: Continuum.

Maynooth University (2018). Maynooth University Strategic Plan 2018-2022. Retrieved from:

https://www.maynoothuniversity.ie/sites/default/files/assets/document/Maynooth_Univ ersity_Strategic_Plan_2018-22_0.pdf

Mernagh, E. (2010). Taking Stock: Ten Years of the Bologna Process in Ireland. Retrieved from: http://www.eurireland.ie/_fileupload/2010/Bologna/Taking\%20Stock\%20$\% 20$ Ten\%20Years\%20of\%20the\%20Bologna\%20Process\%20in\%20Ireland(1).pdf

Mu, G. M. et al (2019). Using English at an International Doctoral Workshop: A Three-level Field Analysis. In Mu, G. M., Dooley, K. \& Luke, A. (Eds.), Bourdieu and Chinese Education: Inequality, Competition and Change (pp. 192-213). New York: Routledge.

Neave, G. (1992). Managing higher education international co-operation: Strategies and solutions. Paris: International Association of Universities. Retrieved from: http://unesdoc.unesco.org/images/0009/000986/098679eb.pdf 
NUI Galway (2015). Vision 2020: NUI Galway Strategic Plan 2015-2020. Retrieved from: https://www.nuigalway.ie/media/nuigalwayie/content/files/aboutus/Vision2020-NUIGalway-Strategic-Plan-Web.pdf

O'Brien (2017). Mid-term Evaluation of Erasmus+ Programme 2014-2020. Retrieved from: http://eurireland.ie/assets/uploads/2017/07/Mid-Term-Report-Ireland-June-2017.pdf

OECD (2015). Education at a Glance 2015: OECD Indicators. Retrieved from: http://dx.doi.org/10.1787/eag-2015-en

Phillipson, R. (2006). 'English, a cuckoo in the European higher education nest of languages?', European Journal of English Studies, (10)1:13-32.

Phillipson, R. (2015). English as threat or opportunity in European higher education. In S. Dimova, A. K. Hultgren \& C. Jensen (Eds.), English-medium instruction in European higher education, Volume 3 (pp. 19-42). Boston: Walter de Gruyter.

Quality and Qualifications Ireland (2013). Green Paper on the International Education Mark. Retrieved from: https://qqi365public.sharepoint.com/Publications/Green\%20Paper\%20on\%20the $\% 20$ International\%2 0Education\%20Mark\%20-\%20For\%20Consultation.pdf

Quality and Qualifications Ireland (2015). Code of Practice for Provision of Programmes of Education and Training to International Learners. Retrieved from: http://www.qqi.ie/Downloads/Code\%20of\%20Practice.pdf

Robertson, S. L. (2010). Globalising UK Higher Education. Centre for Learning and Life Chances in Knowledge Economies and Societies.

Soler, J. (2019). Language Policy and the Internationalization of Universities: A Focus on Estonian Higher Education. Boston: Walter de Gruyter.

Studer, P. \& Werlen, I. (2012). Linguistic Diversity in Europe: Current Trends and Discourses. Boston: Walter de Gruyter.

Trinity College Dublin (2014). Strategic Plan 2014-2019. Retrieved from: https://www.tcd.ie/strategy/strategic-plan-201419.pdf

UNESCO (2019). Project Atlas Infographics. Retrieved from: https://www.iie.org/en/Research-and-Insights/Project-Atlas/ExploreData/Infographics/2019-Project-Atlas-Infographics

University College Cork (2017). Strategic Plan 2017-2022. Retrieved from: https://www.ucc.ie/en/media/support/strategicplanning/UCCStrategicPlan20172022.pdf 
University College Dublin (2016). Global Engagement Strategy 2016-2020. Retrieved from: https://www.ucd.ie/t4cms/UCD16100\%20Global\%20Engagement\%20Strategy\%20onli ne.pdf

University of Limerick (2015). Strategic Plan 2015-2019: Broadening Horizons. Retrieved from: https://www.ul.ie/UL-Strategic-Plan-Broadening-Horizons.pdf

Walsh, J. (2011). 'A quiet revolution- International influence, domestic elites and the transformation of higher technical education in Ireland 1959-72', Irish Educational Studies, 30(3): 365-381.

Walsh, J. (2014). The Transformation of Higher Education in Ireland, 1945-80. In A. Loxley, A. Seery \& J. Walsh (Eds.), Higher Education in Ireland: Practices, Policies and Possibilities (pp. 5-33). London: Palgrave Macmillan.

Wilkinson, R. (2013). The Development of English-Medium Instruction. In A. Doiz, D. Lasagabaster \& J.M. Sierra (Eds.), English-Medium Instruction at Universities: Global Challenges (pp. 3-27). Bristol: Multilingual Matters. 